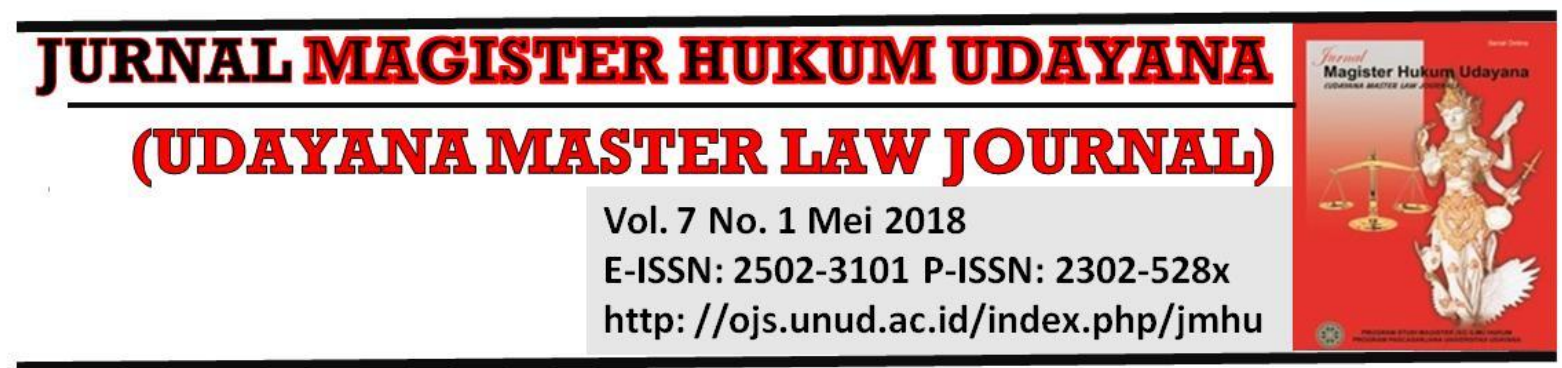

\title{
Urgensi Ratifikasi Konvensi International Labor Organization: Perspektif Perlindungan Pekerja Anak Pada Sektor Rumah Tangga
}

\section{Rika Putri Subekti ${ }^{1}$}

${ }^{1}$ Dinas Pekerjaan Umum dan Penataan Ruang Provinsi Bali, E-mail: khieka@gmail.com

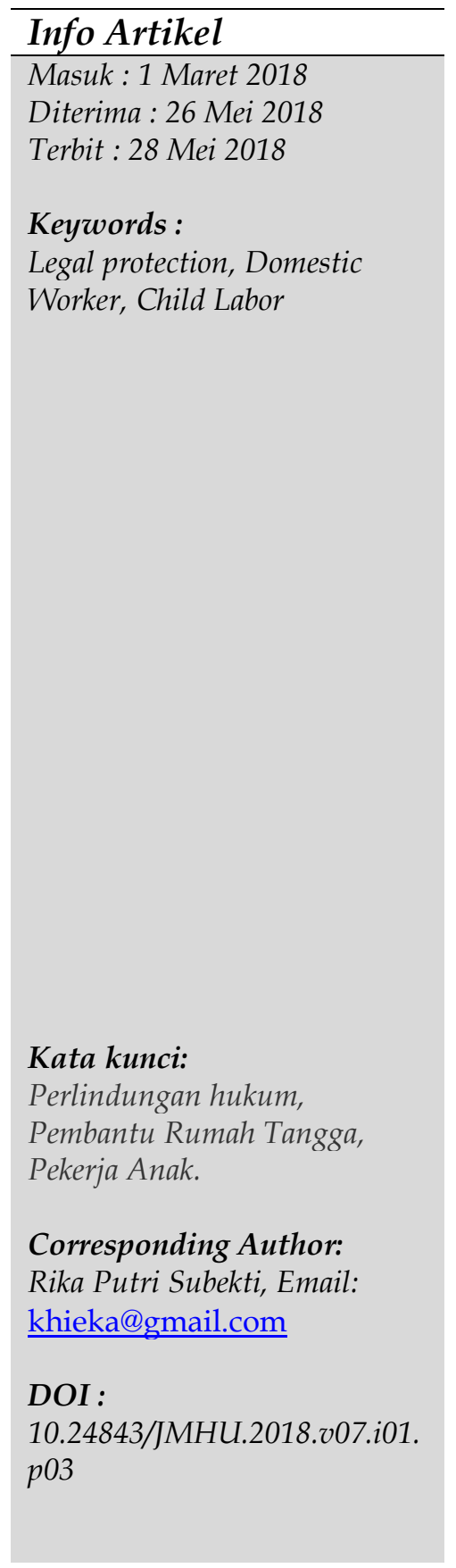

\begin{abstract}
The issue of domestic worker has not become governor of Indonesia policy priorities. This can be seen from the lack of a structure for the comprehensive and lack of regulations that provide solutions, as well as lack of supporting structure of the implementation. The Act of Manpower is not regulating specifically on the protection of domestic workers, especially for children. International Labor Organization Convention Number 189 concerning Decent Works for Domestic Worker, regulates the protection of domestic workers all over the world, however, Indonesia has not ratified this convention yet. This research is normative legal research that using statute and conceptual approach. Data collection techniques used in this study is literature study. The results of the study indicate that the regulation on the protection of child laborers employed as a domestic worker in Indonesia has not been regulated separately so that in the case of legal protection is not sufficient, in the case of law enforcement in case of violation of the law on the rights of the child. The urgency for the Government to immediately ratify ILO Convention No. 189 on Decent Work of Domestic Workers in order to establish a standard of employment for domestic workers as an effort to realize protection for domestic workers in general and for child domestic workers in particular. It is important for government to carry out the National Action Plan for the Elimination of the Worst Forms of Child Labor (RANWFCL) to prevent and eliminate the worst forms of child labor.
\end{abstract}

\begin{tabular}{l} 
Abstrak \\
\hline Isu tentang Pekerja Rumah Tangga (PRT) belum menjadi suatu \\
prioritas kebijakan pemerintah Indonesia. Hal ini terlihat dari \\
belum adanya suatu struktur regulasi yang komprehensif dan \\
solutif, disertai struktur pendukung dalam tataran \\
implementasinya. Ketentuan Undang-Undang tentang \\
Ketenagakerjaan belum mengatur secara khusus mengenai \\
perlindungan terhadap pembantu rumah tangga khususnya bagi \\
anak-anak. Namun telah ada konvensi internasional yang \\
mengatur secara khusus tentang Pekerja Rumah Tangga (PRT) \\
yaitu Konvensi ILO Nomor 189 tentang Kerja Layak Pembantu \\
Rumah Tangga. Konvensi ini merupakan perlindungan bagi \\
pembantu rumah tangga di seluruh dunia. Namun, hingga saat \\
ini Indonesia belum meratifikasi konvensi tersebut. Jenis \\
Penelitian ini adalah jenis penelitian hukum normatif. Jenis
\end{tabular}


pendekatan yang digunakan adalah pendekatan perundangundangan dan pendekatan konseptual. Teknik pengumpulan data yang digunakan dalam penelitian ini adalah studi kepustakaan. Hasil Penelitian menunjukan bahwa pengaturan tentang perlindungan pekerja anak yang dipekerjakan sebagai pembantu rumah tangga di Indonesia belum diatur secara khusus sehingga dalam hal perlindungan hukum belum memadai. Urgensi bagi Pemerintah untuk segera meratifikasi Konvensi ILO Nomor 189 tentang Kerja Layak PRT dalam rangka menetapkan suatu standard ketenagakerjaan bagi PRT sebagai upaya mewujudkan perlindungan bagi PRT secara umum dan bagi PRT Anak pada khususnya. Upaya Pemerintah dalam mewujudkan perlindungan terhadap PRT Anak adalah dengan melakukan Rencana Aksi Nasional Penghapusan Bentuk-Bentuk Pekerjaan Terburuk Bagi Anak (RAN-BPTA) yang bertujuan untuk mencegah dan menghapus bentuk-bentuk pekerjaan terburuk untuk anak.

\section{Pendahuluan}

Perkembangan ekonomi yang cepat berakibat kepada menguatnya pemenuhan akan kebutuhan, oleh karena itu dalam satu keluarga, istri pun ikut bekerja dalam mencari nafkah, dalam hal mengerjakan urusan kerumahtanggaan pun diserahkan kepada pekerja rumah tangga (PRT). Kehadiran PRT ini sangat penting dalam menjalankan peran reproduktif, sehingga istri pun dapat bekerja tanpa perlu mengalami kerepotan dalam hal pekerjaan rumah tangga. ${ }^{1}$ Dalam perkembangannya, tidak hanya istri yang ikut bekerja namun juga anak-anak dalam rangka pemenuhan kebutuhan keluarga salah satunya menjadi pekerja pembantu rumah tangga, kondisi tersebut tidak dapat dipungkiri pada akhirnya menambah jumlah PRT.

Jumlah PRT di Indonesia saat ini mencapai 2,6 juta orang dan 90\% terdiri dari perempuan. Umumnya mayoritas PRT berusia dibawah 30 tahun dan berasal dari daerah pedesaan yang kondisi ekonominya tergolong miskin, akses terhadap pendidikan terbatas dan minimnya lapangan pekerjaan. ${ }^{2}$ Pekerjaan domestik yang dilakukan oleh PRT tidak pernah mendapatkan perhatian khusus dari Pemerintah dan masyarakat. Hingga akhirnya statusnya yang termajinalkan, sangat rentan mengalami kekerasan, eksploitasi dan mengalami pelanggaran atas hak-haknya sebagai pekerja. Kondisi ini tidak terelakkan dikarenakan sampai saat ini belum ada satu peraturan perundang-undangan yang mengatur secara khusus, tegas, dan eksplisit tentang perlindungan PRT di Indonesia. Undang-Undang Nomor 13 Tahun 2003 tentang Ketenagakerjaan hanya mengatur perlindungan atas pekerja di sektor formal. ${ }^{3}$

Berdasarkan laporan Kementerian Negara Pemberdayaan Perempuan yang menggambarkan kondisi PRT di Indonesia sebagian besarnya adalah perempuan, usia

${ }^{1}$ Hidayati, M. N. (2011). Upaya Perlindungan Pekerja Rumah Tangga Sebagai Kelompok Masyarakat Yang Termarjinalkan di Indonesia. Seri Pranata Sosial, 1(1), 11-18, h. 11.

2 Nola, L. F. (2016). Aspek Hukum Larangan Mempekerjakan PRT Anak (Legal Prohibition Employ Child Domestic Workers In Indonesia). Negara Hukum, 3(2), 275-297, h. 275.

${ }^{3}$ Human Rights Watch. (2009). Pekerja di dalam Bayang-Bayang (Pelecehan dan Eksploitasi terhadap Pekerja Rumah Tangga Anak di Indonesia). Jakarta: HRW, h.15-17. 
belum dewasa, dalam kondisi buruk, bekerja tanpa batas waktu yang jelas dan kerap kali mengalami kekerasan fisik dan seksual. Adapun bila dilihat dari usia, sebagian besar PRT masih berusia muda. Beberapa PRT mulai bekerja pada usia antara 10-14 tahun, sedangkan sebagian besar lainnya bekerja pada usia 15-23 tahun. Hal ini disebabkan pekerjaan ini tidak menuntut pendidikan dan tingkat keterampilan yang tinggi. Faktor lainnya adalah permintaan dari Pemberi Kerja (demand side) yang sebagian besar menginginkan PRT yang masih berusia muda (anak) dengan alasan kepatuhan dan gaji yang rendah. Studi RGP pada 173 PRT menunjukkan bahwa usia rata-rata PRT sebagian besar adalah 13-18 tahun (69 orang atau 39,8\%). ${ }^{4}$

Pada hakekatnya anak tidak boleh bekerja karena waktu mereka selayaknya dimanfaatkan untuk belajar, bermain, bergembira, berada dalam suasana damai, mendapatkan kesempatan dan fasilitas untuk mencapai cita-citanya sesuai dengan perkembangan fisik, psikologis intelektual dan sosialnya. Namun pada kenyataannya banyak anak-anak dibawah usia 18 tahun yang telah terlibat aktif dalam kegiatan ekonomi, menjadi pekerja anak antara lain di sector industri dengan alasan tekanan ekonomi yang dialami orang tuanya ataupun faktor lainnya. ${ }^{5}$ Sesungguhnya anak yang bekerja tidak sepenuhnya dilarang, karena anak yang bekerja tidak selalu merugikan atau berdampak negative, sepanjang tujuan anak yang bekerja untuk mengembangkan kemampuan dan rasa ingin tahu serta meningkatkan kreativitas dan kemandirian. ${ }^{6}$

Upaya Pemerintah Indonesia dalam rangka memberikan perlindungan terhadap anakanak yang terpaksa bekerja melalui ratifikasi atas Konvensi International Labor Organisation (ILO) Nomor 138 tentang Usia Minimum untuk Diperbolehkan Bekerja pada Juni 1999 dengan Undang-Undang Nomor 20 Tahun 1999 dan Konvensi ILO Nomor 182 tentang Bentuk-Bentuk Pekerjaan Terburuk untuk Anak pada Maret 2000 dengan Undang-Undang Nomor 1 Tahun 2000. ${ }^{7}$ Sebagai tindak lanjut dari peratifikasian kedua Konvensi tersebut, telah pula disusun Rencana Aksi Nasional (RAN) Penghapusan Bentuk-bentuk Terburuk Pekerja Anak yang telah diberlakukan melalui Keputusan Presiden Republik Indonesia Nomor 59 Tahun 2002 pada tanggal 13 Agustus 2002. ${ }^{8}$ Melalui Keppres tersebut pemerintah juga telah mengidentifikasi 13 jenis pekerjaan terburuk yang melibatkan pekerja anak yang harus ditangani melalui program terikat waktu (time bound programme/TBP). Jenis-jenis pekerjaan terburuk tersebut antara lain anak yang terlibat dalam kegiatan prostitusi; anak yang bekerja di pertambangan, termasuk di dalamnya anak yang bekerja pada industri yang

\footnotetext{
${ }^{4}$ ILO-IPEC. (2004). Bunga-Bunga di Atas Padas Fenomena Pekerja Rumah Tangga Anak di Indonesia. Jakarta: ILO-IPEC, h. 21.

${ }^{5}$ Jannani, N., \& Fikriyah, U. (2017). Refleksi Perlindungan Hukum Terhadap Pekerja Anak Berwawasan Gender. Egalita, 11(1)., h.4.

6 Endrawati, N. (2012). Perlindungan Hukum Terhadap Pekerja Anak Di Sektor Informal (Studi Kasus di Kota Kediri). Jurnal Dinamika Hukum, 12(2), 270-283, h. 271.

7 Tahar, A. M. (2015). Pengaruh Hukum Internasional terhadap Pembentukan Hukum Nasional. Jurnal Selat, 2(2), 227-237., h. 232.

8 Chrisdanty, F. (2017). Harmonisasi Hukum Ketenagakerjaan Dengan Konvensi ILO Dalam Perlindungan Hukum Bagi Anak Yang Bekerja. Maksigama, 10(2), 36-46., h. 41.
} 
menggunakan bahan kimia yang berbahaya. ${ }^{9}$

Sebagian besar anak-anak yang terpaksa bekerja sebagai pekerja rumah tangga bekerja selama 10-14 jam sehari dengan waktu istirahat 1 jam dan tanpa hari libur mingguan. Berdasarkan ketentuan waktu kerja bagi anak dalam Undang-Undang Ketenagakerjaan adalah maksimum 3 jam dalam sehari. Selain pelampauan jam kerja, masalah upah dan hak cuti bagi PRT pun terabaikan, oleh karena belum ada suatu standard ketenagakerjaan yang diatur dalam suatu peraturan perundang-undangan bagi PRT.10

Pekerjaan rumah tangga ini dikategorikan sangat membutuhkan perlindungan hukum dan sosial, meskipun pekerja rumah tangga bekerja pada sektor kerumahtanggaan berbeda dengan pekerja di sektor formal lainnya, akan tetapi sebagai warga negara Indonesia, PRT wajib dihormati, dilindungi dan dipenuhi hak-haknya sebagai pekerja dan hak asasinya sebagai manusia. ${ }^{11}$

Konvensi ILO Nomor 189 Tahun 2011 tentang Kerja Layak Bagi PRT merupakan perlindungan hukum bagi PRT di seluruh dunia dan menjadi landasan untuk memberikan pengakuan dan jaminan bagi PRT untuk mendapatkan kondisi kerja yang layak sebagaimana pekerja di sektor formal. Berdasarkan pemaparan latar belakang diatas, maka dapat dikemukakan permasalahan yang akan dikaji dalam tulisan ini yaitu bagaimanakah bentuk pengaturan perlindungan PR, khususnya pekerja anak dalam Konvensi ILO Nomor 189 tentang kerja layak bagi PRT? Serta bagaimanakah upaya Pemerintah dan ILO dalam mewujudkan perlindungan bagi anak yang dipekerjakan sebagai PRT? Tulisan ini bertujuan untuk menganalisis ketentuan yang mengatur perlindungan pekerja anak pada sector informal dalam lingkup Konvensi ILO Nomor 189. Tujuan selanjutnya untuk memahami dan mengelaborasi upaya pemerintah Indonesia dalam mewujudkan perlindungan bagi anak yang dipekerjakan sebagai pembantu rumah tangga.

Pengaturan tentang perlindungan terhadap perempuan bekerja serta hak untuk bekerja dengan aman dan tidak dibeda-bedakan sesungguhnya merupakan cerminan dari prinsip non diskriminasi sebagaimana diatur dalam Konvensi ILO Nomor 111 tahun 1958. Pengaturan tentang perlindungan anak yang bekerja juga telah diatur melalui Konvensi ILO No. 138 Tahun 1973, Konvensi ini menekankan perlindungan terhadap batas usia minimum untuk anak diperbolehkan bekerja. ${ }^{12}$ Rentannya perlindungan terhadap anak untuk disalahgunakan tidak hanya berkaitan dengan eksploitasi sebagai pekerja anak, namun juga ekploitasi korban perdagangan anak. Hasil studi dari Syaifullah Yophi Ardianto pada tahun 2013 mengkaji tentang anakanak perlindungan anak terkait kasus tindak perdagangan orang, khususnya di Kota

9 Triwardhani, I. J., \& Trigartanti, W. (2012). Pengelolaan Komunikasi Pekerja Anak di Industri Kecil Boneka Kain Kopo Bandung. MIMBAR, Jurnal Sosial dan Pembangunan, 28(2), 211-218., h. 212.

${ }^{10}$ Hardius Usaman dan Nachrowi Djalal. (2004). Pekerja Anak di Indonesia:Kondisi, Determinan dan Eksploitasi (Kajian Kuantitatif). Jakarta: PT. Gramedia Widiasarana Indonesia, h.174.

${ }^{11}$ Departemen Pendidikan Nasional. (2012). Pedoman Teknis Pelayanan Pendidikan Bagi Pekerja Anak Sektor Informal. Jakarta: Depdiknas, h. 8.

12 Nur, J. (2015). Implementasi Kebijakan Pekerja Anak Menurut Konvensi ILO. Konstruktivisme: Jurnal Pendidikan \& Pembelajaran, 7(1), 67-75., h. 74. 
Pekanbaru. ${ }^{13}$ Berkaitan dengan pengaturan perlindungan anak sebagai korban perdagangan juga mengemuka dari hasil studi yang dilakukan oleh Henny Nuraeny dan Tanti Kirana Utami pada tahun 2015.14 Dalam tulisan ini, fokus kajiannya lebih ditekankan pada pengaturan tentang perlindungan bagi PRT dalam Konvensi ILO Nomor 189 tentang Kerja Layak PRT, khususnya perlindungan bagi anak yang bekerja sebagai PRT dalam rangka mewujudkan perlindungan hukum bagi anak di Indonesia.

\section{Metode Penelitian}

Kajian ini menggunakan jenis penelitian hukum normatif. Pada penelitian hukum jenis ini, acapkali hukum di konsepkan sebagai apa yang tertulis dalam peraturan perundang-undangan (law in books) atau hukum dikonsepsikan sebagai kaidah atau norma yang merupakan patokan berperilaku manusia yang dianggap pantas. Sebagai ilmu normatif, "ilmu hukum memiliki cara kerja yang khas dalam membantu memecahkan persoalan-persoalan hukum yang dihadapi masyarakat". Jenis pendekatan yang digunakan adalah pendekatan konseptual dan perundangundangan. Pendekatan perundang-undangan dilakukan dengan menelaah semua undang-undang dan regulasi yang bersangkut paut dengan isu hukum yang sedang ditangani. Pendekatan ini digunakan bagi penulis agar dapat mempelajari adakah konsistensi dan kesesuaian antara suatu undang-undang dengan undang-undang lainnya atau antara undang-undang dengan Undang-Undang dasar atau antara regulasi dan undang-undang. Hasil dari telaah tersebut merupakan suatu argumen untuk memecahkan isu yang diangkat dalam tulisan ini. Pendekatan konseptual beranjak dari pandangan dan doktrin yang berkembang di dalam ilmu hukum. Dengan mempelajari hal tersebut, penulis akan menemukan ide-ide yang melahirkan pengertian-pengertian hukum, konsep-konsep hukum, dan asas-asas hukum yang relevan dengan isu yang diangkat dalam tulisan ini. Teknik pengumpulan bahan hukum primer dan bahan hukum sekunder dengan teknik bola salju, pengumpulan bahan hukum primer berpatokan pada hierarki peraturan perundang-undangan dan begitu pula dalam mengumpulkan bahan hukum sekunder baik berupa buku hukum (text book), penerbitan berkala (journal law review. Teknik analisis bahan hukum menggunakan teknik deskriptif. ${ }^{15}$

\section{Hasil dan Pembahasan}

\subsection{Pengaturan Perlindungan Pekerja Rumah Tangga dalam Konvensi ILO Nomor} 189 tentang Kerja Layak PRT.

Perlindungan hukum adalah perlindungan terhadap harkat dan martabat serta pengakuan terhadap hak-hak asasi manusia yang dimiliki oleh subyek hukum berdasarkan ketentuan hukum dari kesewenang-wenangan. Prinsip perlindungan hukum terhadap tindakan pemerintah bertumpu dan bersumber dari konsep tentang pengakuan dan perlindungan terhadap hak-hak asasi manusia karena menurut sejarahnya di barat lahirnya konsep-konsep tentang pengakuan dan perlindungan

${ }^{13}$ Ardianto, S. Y. (2013). Perlindungan Hukum Terhadap Anak Sebagai Korban Dari Tindak Pidana Perdagangan Orang di Kota Pekanbaru. Jurnal Ilmu Hukum, 3(1), hlm 15.

${ }^{14}$ Nuraeny, H., \& Utami, T. K. (2015). Legal Protection Against Children Who Are Victims of Human Trafficking in Cianjur District Studied by Human Rights Perspective. Jurnal Dinamika Hukum, 15(2), 172-177, h. 176.

15 Diantha, I. M. P. (2016). Metodologi Penelitian Hukum Normatif dalam Justifikasi Teori Hukum. Jakarta: Prenada Media, h. 156. 
terhadap hak-hak asasi manusia diarahkan kepada pembatasan dan peletakan kewajiban masyarakat dan pemerintah. Aspek dominan dalam konsep barat tentang hak asasi manusia menekankan eksistensi hak dan kebebasan yang melekat pada kodrat manusia dan statusnya sebagai individu, hak tersebut berada di atas negara dan di atas semua organisasi politik dan bersifat mutlak sehingga tidak dapat diganggu gugat. Karena konsep ini, maka sering kali dilontarkan kritik bahwa konsep barat tentang hak asasi manusia adalah konsep individualistik. Kemudian dengan masuknya hak-hak sosial dan hak-hak ekonomi serta hak kultural terdapat kecenderungan mulai melunturnya sifat individualistik dari konsep barat. ${ }^{16}$

Urgensi meratifikasi Konvensi ILO Nomor 189 adalah untuk menetapkan standarstandar perlindungan terhadap Pekerja Rumah Tangga di Indonesia yang sampai saat ini masih dalam proses legislasi. ${ }^{17}$ Mengenai ruang lingkup dan definisi PRT, merujuk ketentuan sebagaimana diatur dalam Konvensi ILO 189 tentang Kerja Layak bagi PRT. Dalam pasal 1 dan 2 Konvensi 189, ruang lingkup dan definisi pekerjaan rumah tangga adalah pekerjaan yang dilaksanakan di dalam atau untuk satu atau beberapa rumah tangga. Sedangkan Pekerja Rumah Tangga adalah setiap orang yang terikat di dalam pekerjaan rumah tangga dalam suatu hubungan kerja. Penting untuk digarisbawahi adalah sebagai pengakuan atas profesi dan pekerjaan rumah tangga, maka relasi antara pengguna jasa dan PRT adalah hubungan kerja.

Standarisasi perlindungan PRT sebagaimana diatur dalam Konvensi ILO Nomor 189 tentang Kerja Layak bagi PRT meliputi sebagai berikut:

\subsubsection{Upah.}

Konvensi ILO 189 tentang Kerja Layak bagi PRT, memberikan pedoman soal pengaturan upah. Tepatnya pada pasal (11) "Setiap anggota harus mengambil langkah-langkah untuk menjamin bahwa PRT menikmati cakupan upah minimum, bila cakupan itu ada, dan bahwa pengupahan ditetapkan tanpa diskriminasi berdasarkan jenis kelamin". Pasal (12) yang mengatur tentang mekanisme pembayaran upah yang dapat dilakukan dengan transfer, cek atau secara langsung sesuai dengan peraturan masing-masing negara yang disesuaikan dengan kesepakatan antara PRT dan pemberi kerja. Konvensi ILO 189 melarang pemberian upah dalam bentuk barang. Apabila aturan nasional mengakui model pengupahan dalam bentuk in kind (pemberian dalam bentuk barang), maka ketegori tersebut tidak dapat dimasukan sebagai upah.

\subsubsection{Kebebasan Berserikat.}

Konvensi ILO 189 pasal (3) angka (3) menyebutkan "Memastikan bahwa setiap pekerja rumah tangga dan majikan menikmati kemerdekaan berserikat dan pengakuan yang efektif terhadap perundingan bersama. Negara anggota wajib melindungi hak pekerja rumah tangga dan majikan untuk mendirikan organisasi, sesuai dengan peraturan organisasi yang bersangkutan, untuk bergabung di organisasi, federasi dan konfederasi yang mereka pilih.

${ }^{16}$ Hilmy, U. (2012). Pelanggaran dan Perlindungan Hukum Tenaga Kerja Perempuan di Kabupaten Malang. Mimbar Hukum, 23(3), 566-582., h. 568.

$17 \mathrm{http} / /$ / www.jpnn.com/news/dorong-ratifikasi-konvensi-ilo-demi-pekerja-rumah-tangga, diakses pada 19 Pebruari 2018. 


\subsubsection{Jam Kerja.}

Undang-Undang Perlindungan PRT harus mengatur standar jam kerja layak bagi PRT. Ketentuan mengenai standard jam kerja bagi PRT terdapat pula dalam Konvensi ILO 189 pasal 10 (1) “ Setiap anggota harus mengambil langkah-langkah untuk menjamin perlakuan yang sama antara pekerja rumah tangga dan pekerja pada umumnya dalam kaitannya dengan jam kerja normal, kompensasi lembur, jadwal libur harian dan mingguan dan cuti tahunan yang dibayar sesuai dengan undang-undang nasional dan peraturan atau perjanjian kerja bersama, dengan mempertimbangkan karakteristik khusus pekerjaan rumah tangga".

\subsubsection{Hari Libur dan Cuti.}

PRT bekerja setiap hari dengan jam kerja lebih dari ketentuan sebagaimana jam kerja pekerja sektor formal sebagaimana diatur dalam Undang-Undang Ketenagakerjaan, 7 jam sehari 40 jam satu minggu enam hari kerja dalam seminggu atau 8 jam sehari 40 jam satu minggu untuk lima hari kerja dalam satu minggu dengan hari libur mingguan selama 24 jam berturut-turut. Hak untuk menikmati hari libur dan cuti harus dijamin dalam Undang-Undang Perlindungan PRT. Konvensi ILO Nomor 189 mengatur tentang hari libur sama dengan ketentuan dengan Undang-Undang Ketenagakerjaan, demikian pula dengan hak cuti yang meliputi cuti hari raya keagamaan, cuti melahirkan dan pengajuan libur dalam keadaan tertentu seperti saat ada anggota keluarga yang sakit atau meninggal dunia.

\subsubsection{Kebebasan Bergerak dan Hak Privasi.}

Tempat kerja PRT adalah ruang privat/pribadi pengguna jasa/majikannya yang dikonstruksikan sebagai area tertutup yang membatasi ruang gerak PRT untuk bersosialisasi dan mengekspresikan diri di luar area pekerjaanya. Oleh karena kondisinya yang "privat" sangat sulit dilakukan pengawasan dari pihak luar terhadap majikan PRT tersebut, apabila terjadi pelanggaran atas hak-hak atas PRT sulit untuk diketahui. Konvensi ILO Nomor 189 mengatur hak bagi PRT untuk tetap dapat berkomunikasi dan bersosialisasi dengan keluarganya dan masyarakat lingkungan sekitar di luar rumah majikannya. Konvensi ini juga mengatur pengguna jasa atau majikan agar menyediakan kamar tersendiri bagi PRT dan menyediakan fasilitas untuk menjalankan ibadah sesuai dengan agama yang diyakini oleh PRT.

\subsubsection{Hak atas Keamanan dan Keselamatan Kerja.}

Ketentuan ILO dan WHO (World Health Organization) mengatur tentang standard keamanan dan keselamatan kerja bagi PRT bertujuan untuk :

a. Meningkatkan dan memelihara derajat kesehatan tenaga kerja yang setinggitingginya baik jasmani maupun rohani;

b. Mencegah timbulnya gangguan kesehatan yang disebabkan oleh kondisi kerja;

c. Melindungi tenaga kerja dari bahaya kesehatan yang timbul akibat pekerjaan;

d. Menempatkan tenaga kerja pada suatu lingkungan kerja yang sesuai dengan kondisi fisik, tubuh dan mental psikologis tenaga kerja yang bersangkutan. ${ }^{18}$

18 Komnas Perempuan. (2011). Kertas Posisi Rancangan Undang-Undang Perlindungan Pekerja Rumah Tangga, Jakarta: Komnas Perempuan, h.14. Dokumen dapat diakses pada https://www.komnasperempuan.go.id/kumpulan-kertas-posisi-bermacam-rancanganundang-undang/\#more-12892, diakses pada tanggal 19 Pebruari 2018. 
Konvensi ILO 189 Pasal 13 mengatur bahwa: Setiap pekerja rumah tangga memiliki hak untuk lingkungan kerja yang aman dan sehat. Setiap Negara harus mengambil langkah yang sesuai dengan undang-undang, peraturan dan praktik nasional, langkah yang efektif, dengan memperhatikan karakteristik khusus pekerjaan rumah tangga, untuk memastikan keselamatan dan kesehatan kerja pekerja rumah tangga.

\subsubsection{Hak Informasi.}

Konvensi ILO Nomor 189 mengatur tentang kewajiban Negara untuk menyebarluaskan informasi tentang hak-hak PRT dan pengakuan PRT sebagai pekerja. Penyebarluasan informasi ini harus bersinergi dengan pemerintah daerah. PRT berhak mendapatkan informasi tentang hak-haknya sebagai PRT, tata cara dan mekanisme bekerja yang aman, bebas dari eksploitasi dan perdagangan manusia.

\subsubsection{Kontrak Kerja.}

Konvensi ILO menegaskan relasi pengguna jasa dan PRT sebagai relasi kerja yang diatur dalam kontrak kerja. Kontrak kerja harus mengatur kewajiban kepada para pengguna jasa dan penyalur yang kemudian disepakati para pihak. Konvensi ini memuat aturan mengenai standard kontrak kerja rumah tangga dengan setidaknya memasukkan komponen antara lain; Identitas para pihak, alamat tempat kerja, tanggal mulai dan berakhirnya kontrak, durasi waktu kerja, jenis pekerjaan, pengupahan, hari libur, ketentuan PHK.

Dalam perspektif perlindungan anak, Undang-Undang Dasar 1945 Pasal 28B mengatur bahwa "setiap anak berhak atas kelangsungan hidup, tumbuh-kembang dan perlindungan dari berbagai bentuk kekerasan dan diskriminasi". Pengaturan ini merupakan komitmen nasional oleh Pemerintah untuk memenuhi dan melindungi terhadap hak anak. Komitmen itu tentunya diwujudkan dalam perundangan dan kebijakan nasional, sehingga secara dinamis anak mengalami kondisi yang lebih baik. ${ }^{19}$

Indonesia telah meratifikasi Konvensi Hak Anak (KHA) sebagai instrumen yang digunakan untuk melindungi anak. Konvensi Hak Anak merupakan suatu tonggak sejarah dalam hukum internasional, karena di dalam konvensi tersebut memuat hak anak yang perlu dilindungi oleh setiap negara yang meratifikasinya. Tugas pemerintah adalah mewujudkannya dalam bentuk kebijakan dan program nasional untuk kepentingan terbaik anak (the best interest of the child). Ini dituangkan melalui UndangUndang Nomor 23 Tahun 2002 tentang Perlindungan Anak yang secara tegas mengatur tentang perlindungan terhadap anak dari segala bentuk perlakuan salah, eksploitasi ekonomi, kekerasan, dan perdagangan anak. ${ }^{20}$

Meskipun belum ada suatu peraturan perundang-undangan yang secara khusus mengatur tentang perlindungan terhadap pekerja rumah tangga anak, namun jika mencermati substansi perundang-undangan dan kebijakan yang ada tentu dapat digunakan sebagai pedoman untuk memberikan perlindungan hak-hak dasar kepada

19 Hidayati, N. (2014). Perlindungan Anak terhadap Kejahatan Kekerasan Seksual (Pedofilia). Ragam Jurnal Pengembangan Humaniora, 14(1), 68-73., h. 71.

20 Raflis, R. I., Rochaeti, N., \& Wijaningsih, D. (2016). Perlindungan Hukum Bagi Pekerja Rumah Tangga Perempuan Korban Tindak Kekerasan. Diponegoro Law Journal, 5(3), 1-26., h. 3. 
anak yang terpaksa bekerja. Pandangan yang mesti diutamakan adalah bahwa anak adalah kelompok umur yang masih berada pada masa tumbuh kembang dan memerlukan perlindungan dari semua pihak.

\subsection{Upaya Pemerintah dan ILO dalam Mewujudkan Perlindungan PRT}

Pemerintah Indonesia melalui Keputusan Presiden Nomor 59 tahun 2002 telah mengesahkan Rencana Aksi Nasional Penghapusan Bentuk-Bentuk Pekerjaan Terburuk untuk Anak (RAN-BPTA) yang bertujuan "untuk mencegah dan menghapus bentuk-bentuk pekerjaan terburuk untuk anak" melalui program tiga tahap selama dua puluh tahun. Dalam lima tahun pertama, tujuan-tujuan utama program tersebut adalah untuk:

a. Meningkatkan kesadaran publik bahwa bentuk-bentuk pekerjaan terburuk untuk anak harus dihapuskan;

b. Memetakan keberadaan bentuk-bentuk pekerjaan terburuk untuk anak dan upayaupaya untuk menghapuskannya;

c. Mengembangkan dan memulai pelaksanaan program penghapusan bentuk-bentuk pekerjaan terburuk untuk anak dengan prioritas pada :

d. perdagangan anak untuk eksploitasi seksual;

e. pekerjaan penangkapan ikan lepas pantai;

f. pekerjaan di tambang-tambang;

g. pekerjaan di industri informal pembuatan alas kaki;

h. pekerjaan dalam pembuatan dan perdagangan obat bius. ${ }^{21}$

Rencana Aksi Nasional memberikan garis besar kebijakan nasional untuk secara bertahap mencegah dan menghapus bentuk-bentuk pekerjaan terburuk untuk anak, dan memerlukan strategi-strategi seperti penetapan prioritas, melibatkan semua pihak yang berkepentingan, menggunakan dan mengembangkan potensi nasional secara seksama, dan mengembangkan kerjasama dengan memanfaatkan bantuan teknis dari luar negeri. ${ }^{22}$

Didirikan pada tahun 1919, ILO bertanggung jawab untuk mempromosikan hak-hak di tempat kerja, mendorong kesempatan kerja secara layak, meningkatkan perlindungan sosial dan menguatkan dialog terkait permasalahan dunia kerja. ILO merupakan satusatunya badan PBB yang menyatukan perwakilan pemerintah, pengusaha dan pekerja ke dalam "dialog tripartit" untuk membuat kebijakan dan program terkait perburuhan dan ketenagakerjaan.

Untuk menangani masalah pekerja anak, ILO membentuk Program Internasional untuk Menghapus Pekerja Anak (IPEC) pada tahun 1992 dengan tujuan utama menghapus pekerja anak. Langkah ini diupayakan melalui penguatan kapasitas negara untuk menyelesaikan masalah dan mempromosikan gerakan memerangi pekerja anak. IPEC saat ini ada di 88 negara, termasuk di Indonesia dan merupakan program terbesar di tingkat global.

\footnotetext{
${ }^{21}$ Kalangie, H. (2014). Perlindungan Hukum Atas Hak Pekerja Anak Dalam Sektor Informal Di Indonesia. Lex Crimen, 3(4)., h. 161.

22 Ibid.
} 
Upaya IPEC untuk menghapuskan pekerja anak merupakan tahap yang penting dari agenda pekerjaan yang layak ILO. Pekerja anak tidak hanya menghentikan anak-anak untuk mendapatkan pendidikan dan keterampilan yang dibutuhkan untuk masa depan yang lebih baik, tetapi juga melanggengkan kemiskinan dan berdampak pada ekonomi nasional melalui kekalahan dalam daya saing, produktivitas dan potensi pendapatan. Penarikan pekerja anak melalui pendidikan dan membantu keluarga mereka dengan pelatihan dan kesempatan kerja dapat memberikan kontribusi secara langsung untuk menciptakan pekerjaan yang layak bagi orang dewasa.

Melalui struktur tripartitnya yang unik, Organisasi Perburuhan Internasional (ILO) telah bekerja sama secara erat dengan pemerintah Indonesia, Asosiasi Pengusaha Indonesia (Apindo), dan serikat pekerja untuk menangani berbagai isu yang kompleks terkait pekerja anak di Indonesia selama 20 tahun terakhir. Kemitraan yang telah terjalin panjang antara ILO dan konstituennya, serta pemangku kepentingan melalui tonggak-tonggak pencapaian, pembelajaran dan tantangan-tantangan yang akan dihadapi.

Penandatanganan nota kesepahaman pada tahun 1992 antara pemerintah Indonesia dengan ILO untuk melaksanakan Program Internasional untuk Menghapus Pekerja Anak (IPEC), menandai awal kampanye kerja sama jangka panjang ILO untuk melindungi anak-anak Indonesia dari pekerjaan eksploitatif. Nota Kesepahaman ini dibangun berdasarkan kegiatan sebelumnya di Indonesia terkait advokasi hak-hak anak, yang dimulai tahun 1979 yaitu saat pemerintah Indonesia mengesahkan Undang-Undang tentang Kesejahteraan Anak, dan diikuti oleh Keputusan Menteri tentang Pekerja Anak tahun 1987. Nota ini juga menandai dimulainya kerja sama ILO dengan Indonesia melalui pelaksanaan program IPEC untuk menanggulangi penyebab pekerja anak serta melindungi anak-anak Indonesia dari masa depan mereka.

Kerja sama ILO-pemerintah Indonesia ini kemudian diperkuat lagi tahun 1993, ketika Deklarasi tentang Penghapusan Pekerja Anak di Indonesia ditandatangani oleh seluruh pemangku kepentingan pada Konferensi Nasional pertama tentang Pekerja Anak, yang menghimbau pemerintah untuk mempromosikan penegakan hukum, meningkatkan program pendidikan, dan melanjutkan penelitian tentang perburuhan anak.

Deklarasi ini berdampak signifikan selama dua dasawarsa terakhir, hal ini dapat dilihat dari banyaknya inisiatif tentang pengembangan kebijakan, kapasitas dan pembangunan lembaga, dialog sosial, dan intervensi langsung dalam berbagai bidang seperti pendidikan, advokasi dan kampanye, dan perbaikan kondisi kerja.

Beberapa intervensi utama dan pembelajaran selama 20 tahun terakhir direfleksikan dalam lima tonggak pencapaian: Meningkatkan kesadaran tentang pekerja anak (19921996); Menuju pendekatan berbasis sektor (1997-2001); Meningkatkan kesempatan hidup untuk anak-anak (2002-2006); dan Menangani pekerja anak melalui pendidikan (2007-2011).

Pencapaian-pencapaian ini juga menunjukkan bagaimana kemitraan yang telah terjalin selama 20 tahun ini telah berevolusi, bertransformasi focus dan pendekatannya dalam menangani pekerja anak. Hal ini adalah hasil dari proses pembelajaran secara terus- 
menerus antara pemangku kepentingan yang terlibat. ILO, bersama-sama dengan pemerintah, kemitraan sosial dan organisasi non-pemerintah menangani pekerja anak dan permasalahannya di Indonesia, yakin bahwa tidak ada jalan pintas untuk menghapuskan pekerja anak ini. Semua perlu diupayakan secara terus-menerus dengan melibatkan para pemangku kepentingan dalam jangka waktu yang panjang serta komitmen dari pemerintah akan Indonesia yang bebas pekerja anak di tahun 2022. 23

\section{Kesimpulan}

Pengaturan tentang perlindungan pekerja anak yang dipekerjakan sebagai pembantu rumah tangga di Indonesia belum diatur secara spesifik sehingga dalam hal perlindungan hukum belum memadai, dalam hal penegakan hukum apabila terjadi pelanggaran hukum terhadap hak si anak, baik itu kekerasan fisik maupun tidak dipenuhinya hak-hak si anak dalam hal pengupahan dan pelampauan waktu kerja. Urgensi bagi Pemerintah untuk segera meratifikasi Konvensi ILO Nomor 189 tentang Kerja Layak PRT dalam rangka menetapkan suatu standard ketenagakerjaan bagi PRT sebagai upaya mewujudkan perlindungan bagi PRT secara umum dan bagi PRT Anak pada khususnya. Upaya Pemerintah dalam mewujudkan perlindungan terhadap PRT Anak adalah dengan melakukan Rencana Aksi Nasional Penghapusan Bentuk-Bentuk Pekerjaan Terburuk Bagi Anak (RAN-BPTA) yang bertujuan untuk mencegah dan menghapus bentuk-bentuk pekerjaan terburuk untuk anak. Pemerintah juga bersinergi dengan ILO dalam rangka menghapus pekerja anak.

Pemerintah Indonesia hendaknya membentuk suatu peraturan perundang-undangan khusus yang mengatur pekerja rumah tangga yang berisi ketetapan-ketetapan yang konsisten dengan hukum internasional, dan tidak kurang jika dibandingkan dengan standar aturan yang ada dalam UU Ketenagakerjaan. Peraturan perundang-undangan tersebut harus berisi ketetapan-ketetapan yang menjamin perlindungan yang setara terhadap hak-hak pekerja rumah tangga selaku pekerja di sektor informal.

\section{Daftar Pustaka}

Buku

Diantha, I. M. P. (2016). Metodologi Penelitian Hukum Normatif dalam Justifikasi Teori Hukum. Jakarta: Prenada Media.

Departemen Pendidikan Nasional. (2012). Pedoman Teknis Pelayanan Pendidikan Bagi Pekerja Anak Sektor Informal. Jakarta: Depdiknas.

Usman, H., \& Nachrowi, N. D. (2004). Pekerja anak di Indonesia: kondisi, determinan, dan eksploitasi: kajian kuantitatif. Jakarta: Gramedia Widiasara Indonesia.

Human Rights Watch. (2009). Pekerja di dalam Bayang-Bayang (Pelecehan dan Eksploitasi terhadap Pekerja Rumah Tangga Anak di Indonesia), Jakarta: HRW.

ILO-IPEC. (2004). Bunga-Bunga di Atas Padas Fenomena Pekerja Rumah Tangga Anak di Indonesia, Jakarta: ILO-IPEC.

${ }^{23}$ ILO, 2012, Menghapus Pekerja Anak di Indonesia : Dukungan 20 Tahun, Jakarta, h. 5. 
Jurnal

Ardianto, S. Y. (2013). Perlindungan Hukum Terhadap Anak Sebagai Korban Dari Tindak Pidana Perdagangan Orang di Kota Pekanbaru. Jurnal Ilmu Hukum, 3(1).

Chrisdanty, F. (2017). Harmonisasi Hukum Ketenagakerjaan Dengan Konvensi ILO Dalam Perlindungan Hukum Bagi Anak Yang Bekerja. Maksigama, 10(2), 36-46.

Endrawati, N. (2012). Perlindungan Hukum Terhadap Pekerja Anak Di Sektor Informal (Studi Kasus di Kota Kediri). Jurnal Dinamika Hukum, 12(2), 270-283. http://dx.doi.org/10.20884/1.jdh.2012.12.2.47

Hidayati, M. N. (2011). Upaya Perlindungan Pekerja Rumah Tangga Sebagai Kelompok Masyarakat Yang Termarjinalkan di Indonesia. Seri Pranata Sosial, 1(1), 11-18.

Hidayati, N. (2014). Perlindungan Anak terhadap Kejahatan Kekerasan Seksual (Pedofilia). Ragam Jurnal Pengembangan Humaniora, 14(1), 68-73.

Hilmy, U. (2012). Pelanggaran dan Perlindungan Hukum Tenaga Kerja Perempuan di Kabupaten Malang. Mimbar Hukum, 23(3), 566-582. https://doi.org/10.22146/jmh.16177

Jannani, N., \& Fikriyah, U. (2017). Refleksi Perlindungan Hukum Terhadap Pekerja Anak Berwawasan Gender. Egalita, 11(1), 1-23.

Kalangie, H. (2014). Perlindungan Hukum Atas Hak Pekerja Anak Dalam Sektor Informal Di Indonesia. Lex Crimen, 3(4), 156-164.

Nur, J. (2015). Implementasi Kebijakan Pekerja Anak Menurut Konvensi ILO. Konstruktivisme: Jurnal Pendidikan $\mathcal{E} \quad$ Pembelajaran, 7(1), 67-75. https://doi.org/10.30957/konstruk.v7i1.27

Nuraeny, H., \& Utami, T. K. (2015). Legal Protection Against Children Who Are Victims of Human Trafficking in Cianjur District Studied by Human Rights Perspective. Jurnal Dinamika Hukum, 15(2), 172-177. http://dx.doi.org/10.20884/1.jdh.2015.15.2.344

Nola, L. F. (2016). Aspek Hukum Larangan Mempekerjakan PRT Anak (Legal Prohibition Employ Child Domestic Workers In Indonesia). Negara Hukum, 3(2), 275-297. https://doi.org/10.22212/jnh.v3i2.234

Raflis, R. I., Rochaeti, N., \& Wijaningsih, D. (2016). Perlindungan Hukum Bagi Pekerja Rumah Tangga Perempuan Korban Tindak Kekerasan. Diponegoro Law Journal, 5(3), 1-26.

Tahar, A. M. (2015). Pengaruh Hukum Internasional terhadap Pembentukan Hukum Nasional. Jurnal Selat, 2(2), 227-237.

Triwardhani, I. J., \& Trigartanti, W. (2012). Pengelolaan Komunikasi Pekerja Anak di Industri Kecil Boneka Kain Kopo Bandung. MIMBAR, Jurnal Sosial dan Pembangunan, 28(2), 211-218. https://doi.org/10.29313/mimbar.v28i2.357 


\section{Internet}

JPNN.com. $\quad$ http://www.jpnn.com/news/dorong-ratifikasi-konvensi-ilo-demipekerja-rumah-tangga, diakses pada 19 Pebruari 2018.

Komnas Perempuan. (https://www.komnasperempuan.go.id/kumpulan-kertasposisi-bermacam rancangan-undang-undang/\#more-12892, diakses pada tanggal 19 Pebruari 2018. 